Renaissance

\section{and \\ Reformation}

Renaissance

\section{et \\ Réforme}

New Series, Vol. VII, No. 2

Old Series, Vol. XIX, No. 2
Nouvelle Série, Vol. VII, No. 2 Ancienne Série, Vol. XIX, No. 2

\title{
Contents / Sommaire
}

\section{ARTICLES}

79

Pic de la Mirandole et son mythe, tels que vus par William G. Craven, par Louis

Valke

89

Defining the Genre of the Letter: Juan Luis Vives' De Conscribendis Epistolis, by Judith Rice Henderson

106

Études seiziémistes, by Bodo L.O. Richter

120

Moll Cutpurse as Hermaphrodite in Dekker and Middleton's The Roaring Girl, by Patrick Cheney

135

Foreigners in Quattrocento Rome, by Egmont Lee

\section{BOOK REVIEWS / COMPTES RENDUS}

147

Nannerl O. Keohane, Philosophy and the State in France. The Renaissance to the Enlightenment, compte rendu par Georges-L. Bérubé

150

Christopher Lewis, The Merton Tradition and Kinematics in Late Sixteenth and Early Seventeenth Century Italy, reviewed by E.J. Allin

153

Hugh M. Richmond, Puritans and Libertines. Anglo-French Literary Relations in the Reformation, reviewed by Eugene E. Kuzirian 